https://helda.helsinki.fi

\title{
Sorption of mercury in soils with different humus content
}

\section{Lodenius, M.}

Springer-Verlag New York Inc.

1987

Lodenius, M. et al. 1987. Sorption of mercury in soils with different humus content. Bulletin of Environmental Contamination and Toxicology 39: 593-600.

http://hdl.handle.net/1975/195

Downloaded from Helda, University of Helsinki institutional repository.

This is an electronic reprint of the original article.

This reprint may differ from the original in pagination and typographic detail.

Please cite the original version. 


\title{
Sorption of Mercury in Soils with Different Humus Content
}

\author{
Martin Lodenius, Ari Seppänen, and Sari Autio \\ Department of Environmental Conservation, University of Helsinki, \\ SF-00710 Helsinki, Finland
}

The strong sorption of mercury to humic matter in soil and water has raised the question about the influence of organic matter of different soil types on the mobilization of mercury from soil. Mercury is normally bound to humic and fulvic acids, which may be released in connection with flooding, draining and ditching (Rekolainen et al. 1986, Verta et al. 1986). High mercury contents in $f$ ish from man-made lakes have been reported mainly from temperated regions (e.g. Lodenius et al $1983 \mathrm{a}$, Bodaly et al. 1984). This has been assumed to be a result of the slower metabolism of methyl mercury in cool water but the effect of temperature on the mobilization process is still poorly known.

The sorption and leaching of mercury in three different soils was studied in vit $\underline{\text { r }}$ o using mercury concentrations near the natural level. Soil lysimeters were watered with distilled water or artificial acid rain at two temperatures

\section{MATERIAL AND METHODS}

The experiments were performed using polyethylene lysimeter columns (length $40 \mathrm{~cm}, \phi 6.3 \mathrm{~cm}$; Lodenius et al. 1983b) filled with soil (900g, 0.8 I). The soils were slightly humified sphagnum peat, sand (<2 mm) with a low content of humic matter and fine sand of pure quartz $(0.05-0.2 \mathrm{~mm}, 99.58 \mathrm{siO})$. Some properties of the peat and sand soil samples are given in Table 1. The high $\mathrm{E}_{4} / \mathrm{E}_{6}$-ratios indicate a high portion of small-molecular-weight material (fulvic acids). In one lysimeter set a peat layer $(5 \mathrm{~cm}$ at 20 $\mathrm{cm}$ depth) was inserted within the quartz sand column.

send reprint requests to $M$. Lodenius at the above address. 
Table 1. Some properties of the peat and sand samples used in the experiments.

\begin{tabular}{lllll} 
& $\mathrm{pH}^{1}$ & $\mathrm{C}(8)^{2}$ & $\mathrm{~N}(8)^{2}$ & $\mathrm{E}_{4} / \mathrm{E}_{6}{ }^{3}$ \\
peat & 3.6 & 44 & 1.4 & 12 \\
sand & 4.4 & 0.47 & - & 8.5 \\
\hline
\end{tabular}

1 from $0.02 \mathrm{~N} \mathrm{CaCl} 2$, 2 Hewlett-Packard $185 \mathrm{~B} \mathrm{C}-\mathrm{N}-$ analyzer, 3 ratio of absorbances at 465 and $665 \mathrm{~nm}$ in $0.05 \mathrm{~N} \mathrm{NaHCO}{ }^{-l e a c h a t e}$

Mercury was added superficially as $203 \mathrm{Hg}$-acetate. 10.5 $\mu \mathrm{Ci}(389 \mathrm{kBq})$ of the tracer was added to each column mixed with the carrier so that the total amount of added mercury was 100 ug. Two parallel columns were used for all lysimeters. The leaching from peat and mineral soil samples were studied at two temperatures: $+5^{\circ} \mathrm{C}$ and $+20^{\circ} \mathrm{C}$ (Table 2 ). The acid rain was obtained as described earlier $\left(\mathrm{pH} 3.9,43 \mu \mathrm{M} \mathrm{sO}_{4}=/ 1,40 \mu \mathrm{M}\right.$ $\mathrm{NO}_{3} / \mathrm{l}$; Lodenius et al. $\left.1983 \mathrm{~b}\right)$. The amount of water added to each coIumn was $1920 \mathrm{ml}(12 \times 160 \mathrm{ml})$. The length of the experiment was $50 \mathrm{~d}$.

The leachates were collected periodically during the experiments and the volume, pH, colour (absorbance at $420 \mathrm{~nm}$, and $203_{\mathrm{Hg}-a c t i v i t i e s}$ were measured. The mercury contents of the columns were measured externally from two directions using a one channel gamma-sample counter connected to a printer. External scanning has also been successfully used by semu et al. (1985). The measurements from different soils are not directly comparable and for this reason no unit is given for the distribution of mercury in different soil columns (Figs $1-3$ ).

Table 2. Scheme for the experimental treatments (duplicate columns).

\begin{tabular}{|c|c|c|c|}
\hline Columns & rain $\left(20^{\circ} \mathrm{C}\right)$ & $\mathrm{H}_{2} \mathrm{O} \quad\left(5^{\circ} \mathrm{C}\right)$ & $\mathrm{H}_{2} \mathrm{O}\left(20^{\circ} \mathrm{C}\right)$ \\
\hline peat & $\mathbf{A}$ & B & $\mathrm{C}$ \\
\hline sand & D & $\mathbf{E}$ & $\mathbf{F}$ \\
\hline quartz sand & $\mathbf{G}$ & $\mathrm{H}$ & I \\
\hline quartz-peat-quartz & $\mathbf{J}$ & $\mathbf{K}$ & $\mathrm{L}$ \\
\hline
\end{tabular}




\section{RESULTS AND DISCUSSION}

Significant differences were detected between the different soils analysed (Figs 1-3). As there was a good agreement between the duplicate columns and between the two scanning measurements all the results reported in Figs $1-4$ are means of four determinations. After addition of destilled water the mercury was leached deeper in the sand columns than in the peat or in the quartz sand (Figs 1 and 3 ). In the peat columns two distinct peaks were obtained at $+20^{\circ} \mathrm{C}$ (Fig. 1 ) indicating that the mercury may had been bound as two different compounds. Only one peak appeared at $+50 \mathrm{UC}$ (Fig. 3) or after addition of acid rain (Fig. 2). In the peat and sand columns the mercury had leached into deeper layers at $+5^{\circ} \mathrm{C}$ than at $+20^{\circ} \mathrm{C}$ (Figs 3 and 1 ).

Even in the quartz sand columns significant amounts of mercury were bound (Figs 1-3). In the quartz-peatquartz columns the mercury peak never reached the peat layer and the distribution of mercury resembles that of the pure quartz sand columns.

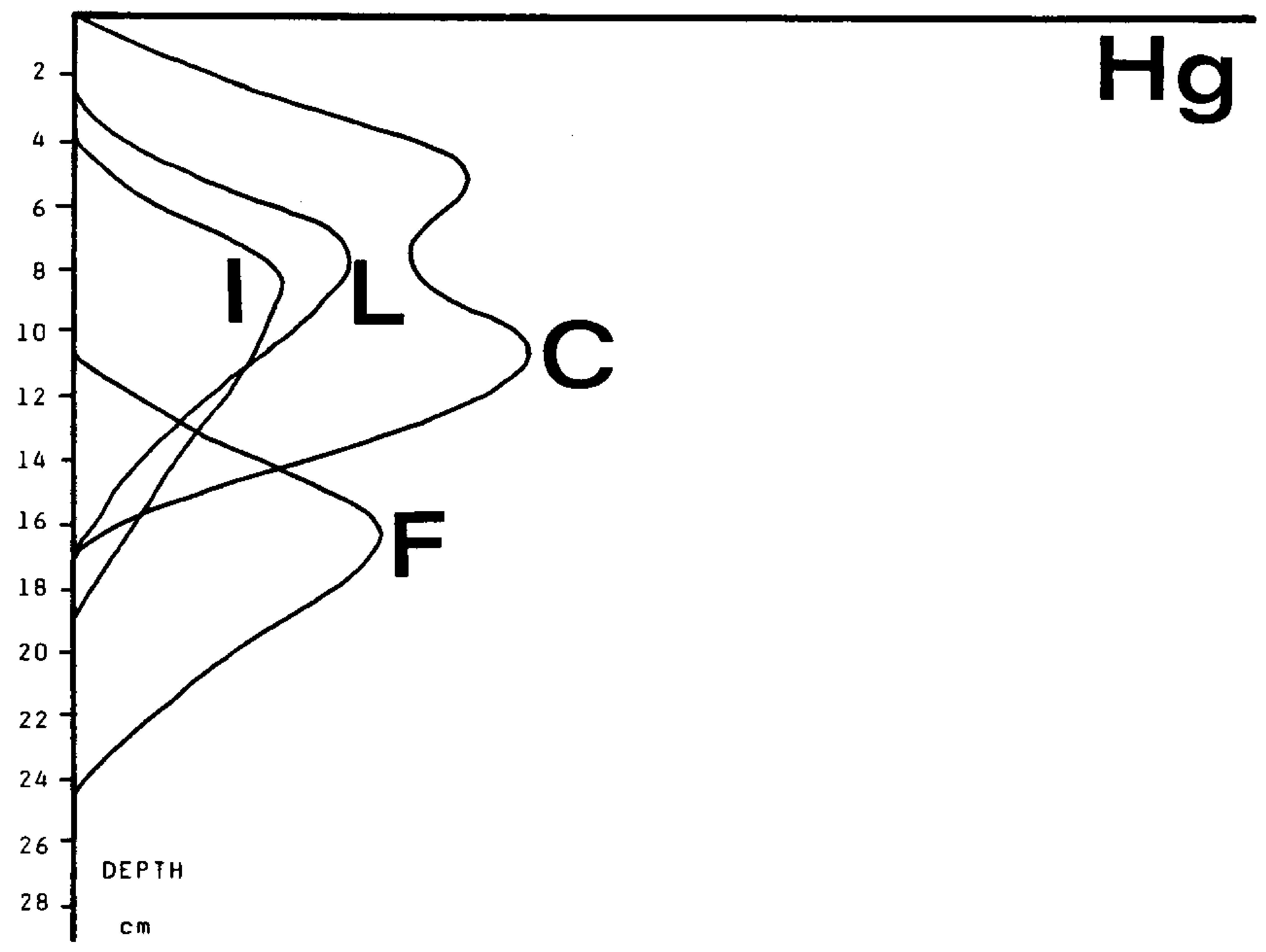

Figure 1 sorption of mercury in $+20^{\circ} \mathrm{C}$ after watering with distilled water. $C=$ peat, $F=$ sand, $I=$ quartz sand, $L=$ quartz-peat-quartz. 

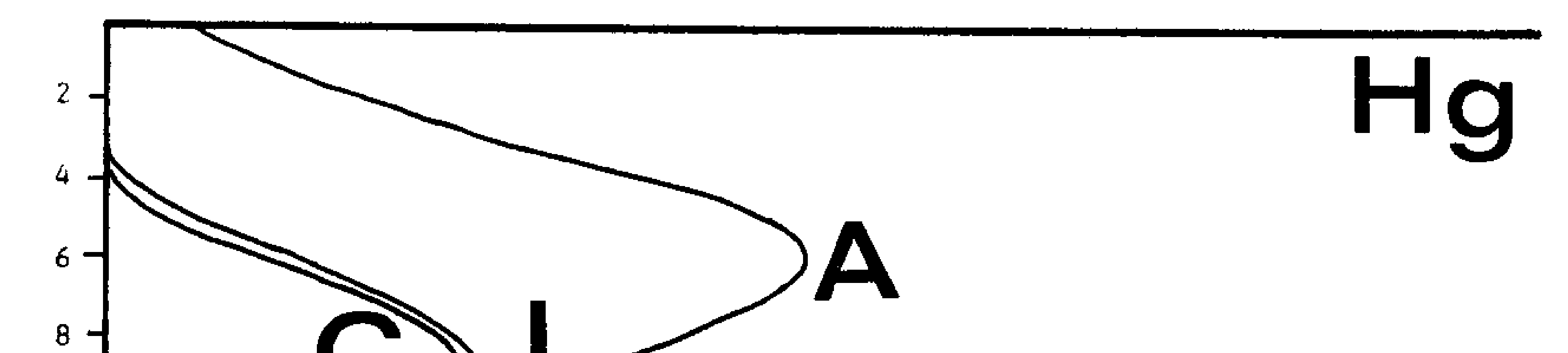

28

Figure 2 sorption of mercury in $+20^{\circ} \mathrm{C}$ a fer watering with acid rain. $A=$ peat,$D=$ sand, $G=$ quartz sand, $J$ = quartz-peat-quartz.

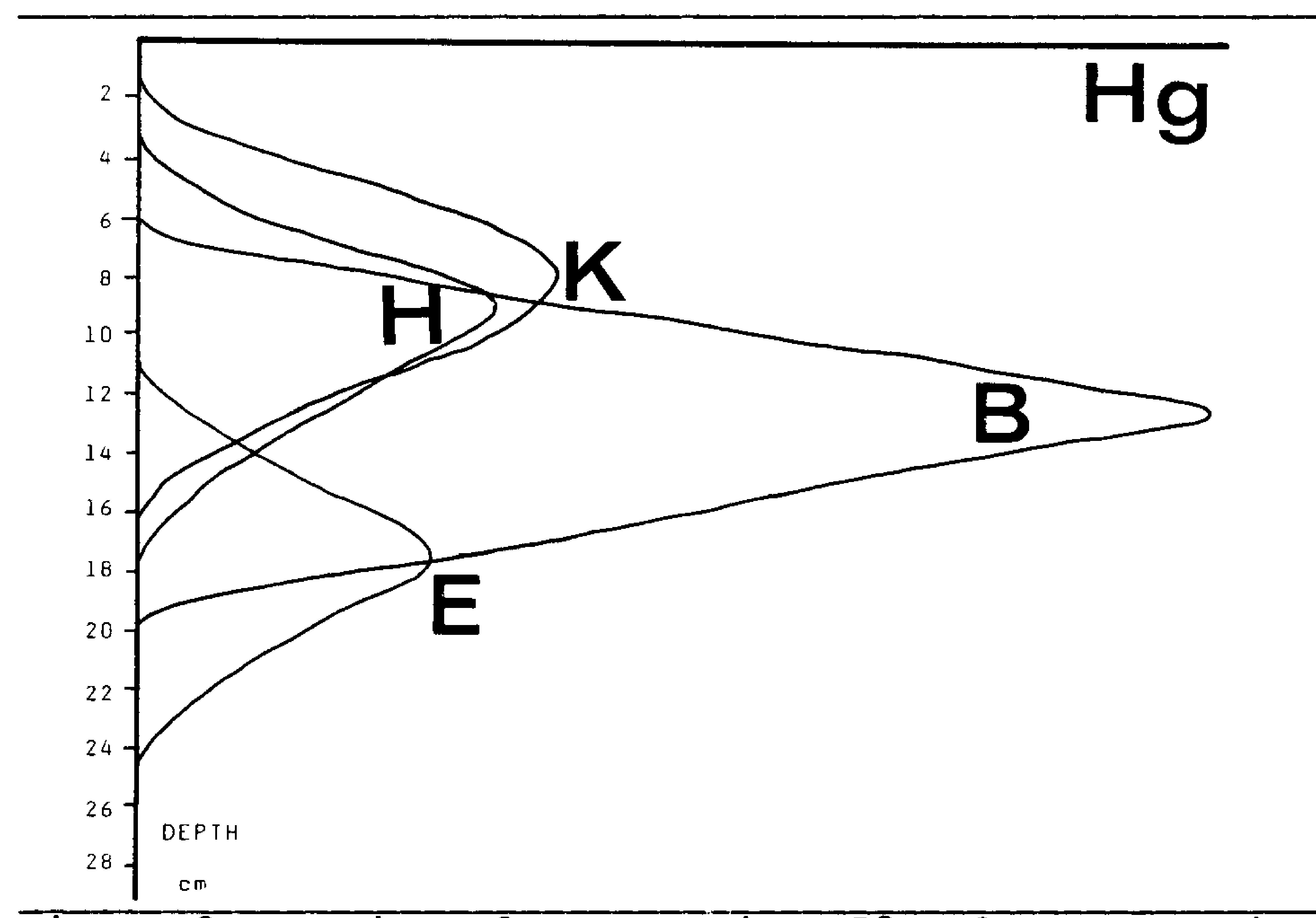

Figure 3 Sorption of mercury in $+5^{\circ} \mathrm{C}$ after watering with distilled water. $B=$ peat, $E$ = sand, $H=$ quartz sand, $K=$ quartz-peat-quartz. 
The addition of acid rain caused a very strong leaching from the pure quartz sand - approximately five times as much as compared with the destilled water (Fig. 4). Low amounts of mercury were leached from the quartzpeat-quartz columns. However, this was not confirmed by any accumulation in the peat layers of these columns. The acidification decreased (approximately three times) the leaching of mercury from sand and peat; the amounts of mercury leached from the sand columns were lower than from the peat columns (Fig. 4).

A decrease of temperature did not affect the leaching of mercury from the peat soil by destilled water but the sorbed amounts were strongly concentrated into one layer about $10 \mathrm{~cm}$ from the top of the column (Fig. 3). Contrary to the other experiments no significant amounts of mercury were detected at the top of any column at this temperature. At $+5^{\circ} \mathrm{C}$ the leaching from sand was four times greater and that from quartz sand three times smaller than at room temperature.

The soil type and the content of organic matter seem to be very important for the sorption of mercury. Even a low humus content is enough to sorbe significant amounts of mercury. Zvonarev and Zyrin (1983) found that most of the mercury in organic soils is bound to sites with high bonding energies, which means that the extractability of mercury is low.

In a lysimeter experiment different metal salts added to pure sand columns were easily removed by leaching while metals (including $\mathrm{Hg}$ ) bound to humic matter were strongly retained (Gomez and Juste 1981). In a clay soil (kaolinite) semu et al. (1986) found a significant correlation between the mercury sorption capacity and the content of organic carbon and the cation exchange capacity while there was a significant negative correlation with the clay content. All these correlations were insignificant for sandy soils. Aomine and Inoue (1967) found that the soil mineral matter contributed little to the sorption of inorganic mercury even though it was important for the sorption of phenyl mercury. In our pure mineral soil mercury was sorbed but the sorption was weak especially at acid conditions.

The two mercury peaks observed in the peat columns (Fig. 1) in this experiment (but not in the previous one; Lodenius et al. $1983 \mathrm{~b}$ ) indicate a partial transformation of the mercury or a binding to two different organic fractions. This transformation is prevented by a low temperature and by addition of acid rain. As $\mathrm{pH}$ does not influence the binding of mercury to different organic fractions (Lodenius \& seppänen 


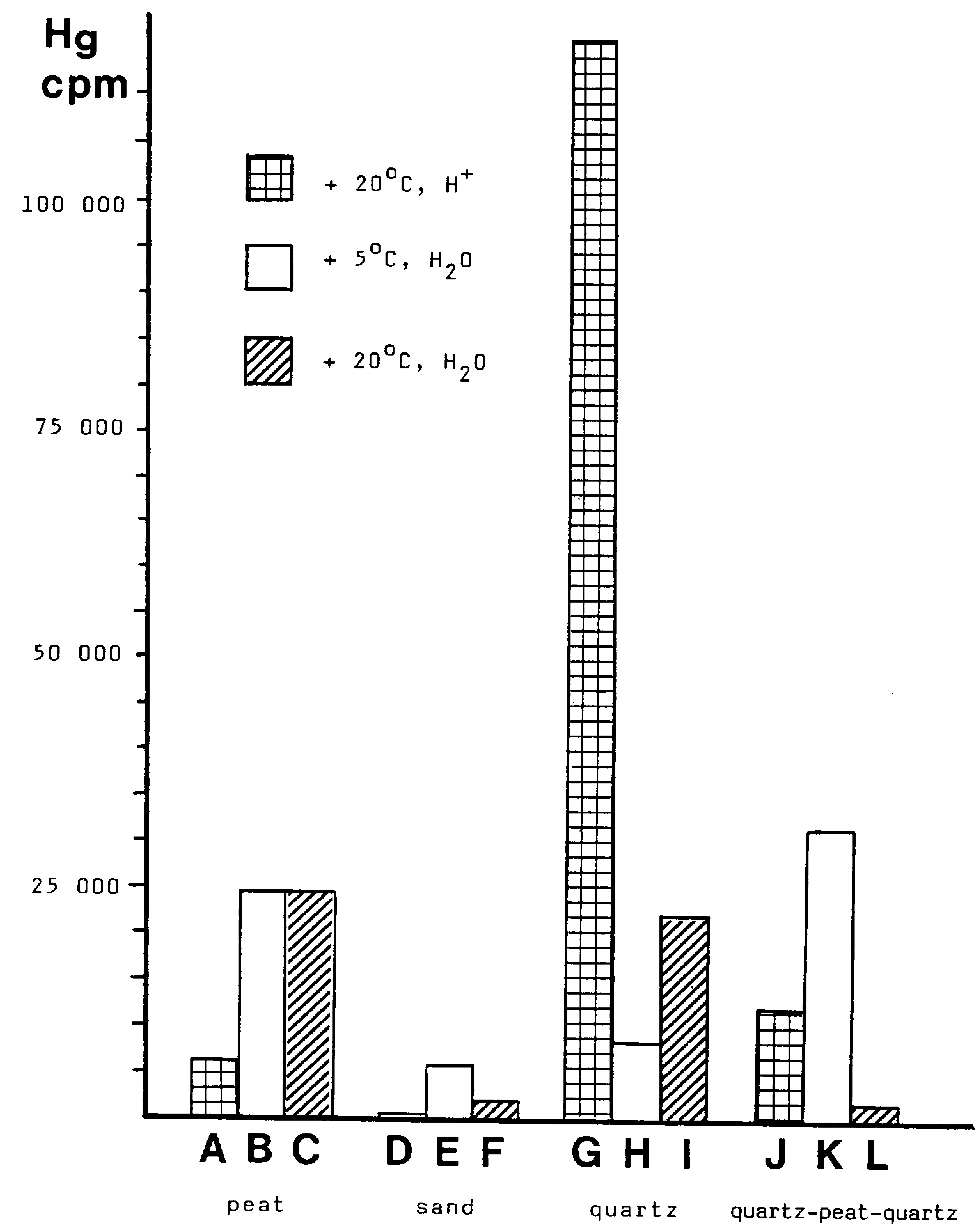

Figure 4 Total leaching of mercury (cpm) from the different columns. 
1984) it seems not likely that these peaks would have been caused by binding to different organic fractions. possibly the lower peak might be methyl mercury which is more soluble than mercury acetate and wich may be formed in the presence of humic substances (eg. Lee et al. 1985 ).

Gomez and Juste (1981) have characterized the humic substances binding heavy metals. The chemical composition of mercury humate differed from those of other metals ( $\mathrm{Pb}, \mathrm{Ni}, \mathrm{Cd})$ having a smaller ash content and a bigger Na-content. The amounts of mercury bound to the humic matter corresponded only partially to the exchange capacity of the soil while it corresponded well to it for the other metals.

The effects of temperature on the leaching of mercury were significant, although opposite, for the sand and quartz columns and not for the peat columns but the reasons for these effects are not known.

Acknowledgments. We are indebted to Jouko Sare'n, Esa We also thank the Finni-Rauva for technical assistance. Natural Natural Resources and the Academy of Finland for financial support.

\section{REPERENCES}

Aomine S, Inoue $\mathrm{K}$ (1967) Retention of mercury by soils. I Adsorption of phenyl mercury acetate by soil colloids. Soil Sci Plant Nutr 13:195-200.

Bodaly RA, Hecky RE, Fudge JP (1984) Increases in $f$ ish mercury levels in lakes flooded by the Churchill River diversion, Northern Manitoba. Can J Fish Aquat Sci 41:682-69l.

Gomez A, Juste C (1981) Mobilite'du cadmium, du mercure, du nickel et du plomb associe's a des acides humiques ou a des anions mine'raux dans des colonnes de sable. In: "Migrations organo-minerales dans les sols tempere's", Centre National de la Recherche Scientifique, Paris, 291-296.

Lee $Y-H$, Hultberg $H$, Andersson I (1985) Catalytic effect of various metal ions on the methylation of mercury in the presence of humic substances. Water Air Soil pollut 25:391-400.

Lodenius $M$, seppänen $A$, Herranen $M$ (1983a) Accumulation of mercury in fish and man from reservoirs in northern Finland. Water Air soil pollut 19: 237-246.

Lodenius M, Seppänen A, Uusi-Rauva A (1983b) Sorption and mobilization of mercury in peat soil. Chemosphere 12: 1575-1581. 
Lodenius M, Seppänen A (1984) Kvicksilvrets bindning till humus $i$ vatten (Summary: Binding of mercury to aquatic humus). Vatten 40:302-307.

Rekolainen S, Verta M, Liehu A (1986) The effect of airborne mercury and peatland drainage on sediment mercury contents in some Finnish forest lakes. Publ Water Res Inst, Nat Bd Waters Finland 65:11-20.

Semu E, Singh BR, Steenberg K, Selmer-Olsen AR (1985) Mobility of $203 \mathrm{Hg}-$ labelled mercuric chloride in soil columns. Acta Agric Scand 35:129-135.

Semu E, Singh BR, Selmer-Olsen AR (1986) Adsorption of mercury compounds by tropical soils. Water Air Soil Pollut 27:19-27.

Verta M, Rekolainen S, Mannio J, Surma-Aho K (1986) The origin and level of mercury in Finnish forest lakes. Publ Water Res Inst, Nat Bd Waters Finland 65:21-31.

Zvonarev BA, Zyrin NG (1983) Relationships governing the sorption of Hg(II) by soils. Desorption of adsorbed mercury from soils by different extractions. Vestnik Moskov Univ, Pochvovedenie 38(3):29-32.

Received January 11, 1987; accepted June 16, 1987. 